\title{
Interactive comment on "Potential yield simulated by Global Gridded Crop Models: a process-based emulator to explain their differences" by Bruno Ringeval et al.
}

\section{Anonymous Referee \#1}

Received and published: 19 August 2020

Great Job!

Interactive comment on Geosci. Model Dev. Discuss., https://doi.org/10.5194/gmd-2020-113, 2020. 